\title{
MENINGKATKAN KEMAMPUAN PEMERINTAH DAERAH DALAM TATA KELOLA LAYANAN PUBLIK MELALUI PEMANFAATAN MODAL SOSIAL
}

\author{
Karoline RS Wenggi \\ Institut Pemerintahan Dalam Negeri (IPDN) \\ Email: karowenggi20@gmail.com
}

\begin{abstract}
Abstrak
Selama beberapa dekade terakhir tata kelola pemerintahan telah bergerak ke arah desentralisasi. Pemerintah daerah diberi kewenangan yang lebih luas dalam mengatur daerahnya sendiri. Akan tetapi setiap daerah sangat beraneka ragam dalam kemampuan melaksanakan tata kelola pemerintahan. Untuk itu diperlukan meningkatkan kemampuan masing-masing daerah dalam menjalankan tata keola pemerintahannya. Bentuk kemampuan ini dapat dilakukan dengan memanfaatkan modal sosial yang dimiliki daerah tersebut. Maka Penelitian ini bertujuan untuk membahas kemampuan daerah dalam tata kelola administrasi publik melalui pemanfaatan modal sosial menyoroti cara-cara di mana pemerintah daerah dapat berkontribusi secara posititif untuk pembentukan modal sosial dengan membuka struktur peluang politik mereka dan melibatkan organisasi nirlaba dan kelompok masyarakat dalam pengaturan kemitraan berbasis kepercayaan. Penelitian ini bersifat kualitatif dengan menggunakan metode tinjauan pustaka dalam menganalisa obyek yang di teliti.
\end{abstract}

Kata Kunci: Modal Sosial, Pemerintah Daerah, Organisasi Nirlaba, Komunitas, Struktur Peluang Politik

\begin{abstract}
Over the last few decades governance has moved towards decentralization. Local governments are given broader authority in regulating their own regions. However, each region varies widely in their capacity to implement governance. For this reason, it is necessary to increase the capacity of each region in carrying out governance. This form of ability can be done by utilizing the social capital that the area has. Thus this study aims to discuss local capacities in public administration governance through the use of social capital highlighting ways in which local governments can contribute positively to social capital formation by opening up their political opportunity structures and engaging non-profit organizations and community groups in partnership-based arrangements trust. This research is a qualitative research using literature review method in analyzing the object under study.
\end{abstract}

Keywords: Social Capital, Local Government, Non-profit Organization, Community, Political Opportunity Structure.

\section{A. PENDAHULUAN}

Selama dua dekade terakhir gelombang reformasi global pemerintahan daerah telah terjadi dengan latar belakang perubahan ekonomi dan politik yang luas (Dollery \& Robotti, 2007). Terlepas dari keragaman di antar negara yang cukup besar dalam fungsi yang dilakukan oleh pemerintah daerah, sumber pendapatan pemerintah daerah dan prinsip-prinsip 
yang menjadi aturan dalam hubungan antara pemerintah daerah dengan pemerintah pusat, gelombang reformasi ini telah dikaitkan dengan proses modernisasi yang telah lain di balik tren global menuju kompleksitas yang lebih besar di sektor publik lokal (Bel dkk., 2007).

Sebagai akibat dari tren ini, pembuat kebijakan harus menilai kembali keunggulan kelembagaan komparatif dari pemerintah daerah yang baru dalam penyampaian layanan publik kepada masyarakat mereka (Siti Maryam, 2017). Dua pandangan yang berbeda muncul di subsistem kebijakan yang mengelilingi pemerintah daerah di negara-negara di mana proses modernisasi ini relatif maju. Di satu sisi, struktur multiguna dari lembagalembaga ini dan kebijaksanaan yang sering mereka miliki dalam menentukan cakupan layanan masyarakat yang ingin mereka sediakan dan mekanisme penyampaian yang mereka gunakan dalam menyediakannya telah menjadi sumber perhatian sejak karakteristik ini membuatnya sulit untuk menempatkan mereka pada garis vertikal otoritas di mana mereka dapat dipertanggungjawabkan untuk keluaran yang ditentukan dengan jelas (Castles, 2003). Di sisi lain, beberapa pembuat kebijakan berpendapat bahwa karakteristik yang sama inilah yang membuat pemerintah daerah yang dimodernisasi sangat cocok dengan peran mereka sebagai pembuat tata kelola masyarakat. Pandangan ini secara khusus telah membentuk pemerintah daerah.

Tampaknya ada dua cara utama di mana pemerintah daerah dapat terlibat dalam kemitraan multi-organisasi. Pertama, pemerintah daerah dapat mengkooptasi lembagalembaga lokal, bersama dengan organisasi lain, ke dalam inisiatif kebijakan yang ditargetkan pada komunitas lokal. Kedua, pemerintah daerah dapat menjalankan inisiatif mereka sendiri dalam membentuk pengaturan kemitraan kolaboratif dengan organisasi lain (Suprapto, 2003). Contoh umum dari hal ini adalah di mana pemerintah daerah bergabung dengan para pemimpin bisnis dan perguruan tinggi setempat untuk memfasilitasi pengembangan usaha kecil atau mengembangkan strategi untuk membuat daerah setempat lebih menarik untuk investasi baru. Di banyak negara, pemerintah daerah telah aktif dalam membangun hubungan kolaboratif dengan pemilik bisnis, organisasi nonprofit dan asosiasi masyarakat di bidang regenerasi perkotaan dan pedesaan serta dalam sektor kepedulian sosial, pendidikan, lingkungan dan kebijakan lainnya.

Selama periode yang sama, pelaksanaan reformasi manajemen publik berdasarkan doktrin Manajemen Publik Baru/New Public Management (NPM) juga telah memperluas cakupan kemitraan multi-organisasi. Secara khusus, restrukturisasi struktur birokrasi besar menjadi lembaga-lembaga dengan tujuan tunggal yang, dalam beberapa kasus, telah dijual ke sektor swasta, dan, dalam kasus lain, disimpan masing-masing (Farazmand \& Balilaj, 2015). 
Lainnya melalui pengaturan pasar semu, seperti pemisahan pembeli-penyedia, cenderung meningkatkan fragmentasi sektor publik. Karena berbagai lembaga berbeda yang bertanggung jawab untuk membentuk dan melaksanakan kebijakan telah meningkat secara dramatis, masalah koordinasi horizontal yang muncul di "medan polisentris" ini sering kali ditangani di tingkat lokal di mana kemitraan menyediakan sarana mengembangkan arah strategis dan menjaga koordinasi (Hardin dkk, 2003).

Namun, pemerintah daerah tampaknya sangat bervariasi dalam kapasitas mereka untuk memainkan peran katalitik dalam pembentukan kemitraan multi-organisasi dan, secara lebih umum, berfungsi sebagai pemasok tata kelola masyarakat dan promotor pembangunan masyarakat. Penulis akan berusaha untuk menunjukkan bagaimana modal sosial dapat mempengaruhi kapasitas jaringan pemerintah daerah dan menyarankan strategi yang dapat berkontribusi secara positif untuk pembentukan sumber daya ini di komunitas mereka. Implikasinya terhadap model pemberdayaan otoritas yang dapat mendasari kebijakan pemerintah daerah akan dipertimbangkan sebagai bahan pertimbangan dari makalah ini.

\section{B. METODE}

Penelitian modal sosial dan kapasitas pemerintah daerah ini menggunakan pendekatan kualitatif dengan metode tinjauan pustaka. Peneliti kualitatif juga menganggap diri mereka sebagai "instrumen" dalam sains, sehingga semua kesimpulan, persepsi, dan cara disaring melalui lensa pribadinya. Untuk alasan ini, ketika menulis metode analisis kualitatif, penting untuk fokus pada strategi anda dan memberikan penjelasan rinci tentang pilihan yang Anda buat saat mengumpulkan dan mengevaluasi data (Moleong, 2007).

\section{HASIL DAN PEMBAHASAN}

Konsep modal sosial telah dipopulerkan oleh Coleman, ia mendefinisikan modal sosial sebagai ciri-ciri kehidupan sosial yang memungkinkan para peserta untuk bertindak bersama secara lebih efektif untuk mengejar tujuan bersama. Tidak seperti modal fisik atau manusia, modal sosial bukan milik individu atau institusi. Sebaliknya hal tersebut diproduksi di ruang antara orang-orang dan mempengaruhi kemampuan mereka untuk bergaul satu sama lain, terutama di luar hubungan yang bersifat langsung. Seperti bentuk modal lainnya, ia produktif tetapi berbeda dalam hal memperkuat diri dan kumulatif (Coleman, 1993). Coleman mengidentifikasi komponen kunci dari modal sosial dan berpendapat bahwa pembentukannya adalah prasyarat untuk pembangunan ekonomi serta pemerintahan yang 
efektif. Penemuan ini telah menarik minat yang cukup besar dalam berbagai bidang profesi (Dinda, 2008).

Komponen kunci dari modal sosial yang diidentifikasi oleh semua ahli adalah jaringan keterlibatan warga, norma timbal balik yang digeneralisasi dan hubungan kepercayaan sosial (Syahra, 2003). Mereka menarik dari teori permainan untuk menunjukkan bahwa melalui interaksi berulang dalam jaringan yang terutama "horizontal" menyatukan agen dengan status dan kekuasaan yang setara, norma-norma ditanamkan dan dipertahankan oleh pemodelan dan sosialisasi (termasuk pendidikan kewarganegaraan) dan oleh sanksi (Putnam, 2000). Yang paling penting dari norma-norma ini adalah timbal balik umum yang 'mengacu pada hubungan pertukaran yang berkelanjutan yang setiap saat tidak terbalas atau tidak seimbang, tetapi itu melibatkan harapan bersama bahwa manfaat yang diberikan sekarang harus dibayar kembali di masa depan. Pembentukan norma ini akan memungkinkan jaringan padat pertukaran sosial terbentuk di mana orang dapat yakin bahwa kepercayaan akan dibalas, bukan dieksploitasi. Penting untuk ditekankan bahwa stok modal sosial tidak spesifik untuk jaringan mana pun. Ini adalah sumber daya khusus area yang dapat digunakan oleh jaringan di lokasi tertentu sehingga ditambah daripada dihabiskan oleh aktivitas jaringan ini (Ancok, 2003). Dengan demikian, persediaan modal sosial di wilayah tertentu mungkin merupakan produk dari tradisi panjang keterlibatan sipil.

Berbagai mekanisme telah diusulkan di mana elemen modal sosial dapat berkontribusi untuk hasil yang lebih baik dengan memfasilitasi kerjasama yang lebih besar. Paling signifikan dari perspektif yang diambil dalam makalah ini, Putnam \& Leonardi (1993), mengemukakan hubungan langsung antara kapasitas administrasi lembaga publik dan modal sosial. Dia menghubungkan variasi regional dalam kemanjuran sektor publik di Italia dengan kepadatan kehidupan pergaulan, menemukan, misalnya, bahwa semakin besar kemungkinan warga suatu wilayah untuk bergabung dengan klub sepak bola dan perkumpulan paduan suara, semakin cepat pemerintah daerah dalam mengganti klaim perawatan kesehatan.

Dasgupta (2005), baru-baru ini menemukan bukti bahwa modal sosial adalah penentu kinerja ekonomi yang dapat diukur. Dia menemukan hubungan posiitif yang signifikan antara dua variabel pertama dan tingkat pertumbuhan, mereka juga menetapkan bahwa keanggotaan kelompok tidak signifikan dalam persamaan pertumbuhan atau investasi (Dasgupta, 2005). Mereka menjelaskan tidak pentingnya aktivitas asosiasi sebagai prediktor pertumbuhan dengan menyarankan bahwa efek positif Putnam (2000) sesuai dengan variabel ini dalam mendorong kerja sama yang lebih besar dan solidaritas yang dapat digunakan dalam menyelesaikan masalah aksi kolektif akan diimbangi oleh efek negatif yang dimiliki 
kelompok pada pertumbuhan ketika mereka bertindak sebagai organisasi pencari keuntungan (Heckelman, 2007), melobi kebijakan preferensial yang membebankan biaya yang tidak proporsional pada masyarakat lainnya. Dalam menyelidiki determinan dari variabel modal sosial yang signifikan, Annen (2003) menemukan bahwa mereka lebih kuat di negara-negara di mana polarisasi sosial yang rendah, dan aturan kelembagaan formal yang membatasi pemerintah untuk bertindak sewenang-wenang, dikaitkan dengan pengembangan norma kerjasama dan kepercayaan.

Temuan ini sangat penting karena menunjukkan bahwa modal sosial hanya dapat meningkatkan kapasitas lembaga pemerintah dan pertumbuhan ekonomi di mana ia mempromosikan kohesi sosial, sebuah tujuan yang diwujudkan dalam 'masyarakat di mana orang bekerja untuk mencapai tujuan bersama dan di mana keragaman diakui tetapi tidak jatuh ke dalam konflik (Fafchamps, 2006). Namun, komunitas yang ikatan sosial antar anggotanya kuat tidak selalu meningkatkan kohesi sosial. Mereka mungkin sangat memusuhi orang luar sehingga mereka dapat memicu konflik sipil, ras atau suku seperti yang cenderung terjadi pada geng, mereka mungkin mempromosikan perilaku ilegal atau tercela secara moral (Agung dkk, 2018).

Secara umum modal sosial yang terbentuk dalam konteks masyarakat yang kohesif dapat menurunkan biaya transaksi yang terkait dengan pasar, hierarki dan jaringan. Namun demikian, efeknya pada kepadatan interaksi jaringan antara pemerintah daerah dan organisasi nirlaba telah menarik perhatian para analis kebijakan pemerintah daerah (Suharto, 2000).

Para ahli bagaimanapun berhati-hati terhadap pendekatan yang didasarkan pada asumsi bahwa adalah mungkin untuk membaca implikasi untuk pemerintahan dari pengetahuan tentang kuantitas dan kualitas kegiatan asosiasi di daerah tertentu. Hubungan antara modal sosial dan kapasitas jaringan pemerintah daerah harus didasarkan pada analisis tentang bagaimana "struktur peluang politik" (Kriesi, 1996) mempengaruhi akses ke, dan pembentukan, modal sosial di lokalitas tertentu. Selain itu, sejauh struktur peluang politik (SPP) dapat dimodifikasi melalui kebijakan pemerintah daerah, harus ada penilaian ulang implikasi dari klaim Putnam (2000) bahwa kebijakan pemerintah tidak dapat berbuat banyak untuk mempengaruhi akumulasi modal sosial.

Sejumlah kontributor teori gerakan sosial baru telah berusaha untuk menyempurnakan konsep struktur peluang poltik (SPP). Meyer \& Staggenborg (1996) menggunakan istilah ini untuk menggambarkan bukaan, titik lemah, penghalang dan sumber daya dari sistem politik itu sendiri. Kriesi (1996) mendefinisikan SPP sebagai dimensi lingkungan politik yang memberikan insentif bagi orang untuk melakukan tindakan kolektif dengan mempengaruhi 
ekspektasi mereka akan keberhasilan atau kegagalan dan menyarankan bahwa dimensi ini akan mengalami perubahan yang signifikan. Melalui terbukanya akses ke kekuasaan, pergeseran keberpihakan, ketersediaan sekutu yang berpengaruh, dan perpecahan di dalam dan di antara para elit.

Para ahli menyarankan bahwa konsep ini dapat digunakan untuk memahami bagaimana perubahan dalam SPP mempengaruhi kemampuan asosiasi sukarela untuk terlibat dengan pemerintah daerah jika pertimbangan diberikan pada tiga sifat sistem politik di mana hubungan tersebut berlangsung (Bowless \& Gintis, 2002). Yang pertama adalah struktur kelembagaan formal yang tercermin dalam tingkat desentralisasi, tingkat koherensi dalam administrasi publik dan kapasitas pemerintah daerah untuk memaksakan kondisi atau persyaratan untuk bekerja sama dengan organisasi nirlaba atau komunitas. Kedua adalah cara informal di mana pengaturan ini diterapkan, otoritas yang cukup jelas berbeda dapat mengembangkan budaya yang berbeda menuju sektor sukarela. Ini dapat berkisar dari pengecualian penuh hingga keterlibatan terbatas hanya dengan kelompok-kelompok yang memiliki pandangan ideologis atau latar belakang profesional dari pejabat hingga pendekatan integratif yang aktif yang berusaha untuk membuat kontak dan membangun hubungan dengan kelompok-kelompok yang sebelumnya terpinggirkan. Ketiga, keterlibatan asosiasi dipengaruhi oleh konteks politik dalam pemerintah daerah karena sifat keberpihakan politik dan konflik di antara elit politik dan kehadiran dan ketiadaan teman dapat menciptakan celah bagi organisasi untuk menghubungkan dengan faksi mencari dukungan dari sektor ini (DeFilippis, 2001).

Kegunaan konsep ini dapat diilustrasikan dengan mengacu pada kemungkinan dampak pada ketiga elemen SPP dari implementasi doktrin New Public Management (NPM) di tingkat lokal. Paling tidak, hal ini akan meningkatkan koherensi dalam penyelenggaraan pemerintahan daerah karena kewenangan pengelolaan terkonsentrasi di tangan kepala daerah. Terlebih lagi, karena pejabat ini akan memiliki keleluasaan untuk mempertimbangkan alternatif kelembagaan untuk ketentuan birokrasi, lebih banyak peluang untuk terlibat dengan kelompok sukarela dan komunitas mungkin muncul. Namun, kritik terhadap NPM cenderung menekankan dampak yang berpotensi merusak yang dapat ditimbulkannya pada modal sosial yang dibentuk melalui kolaborasi antara pemerintah daerah dan sektor sukarela. Burstein (1998) berpendapat bahwa fitur yang paling mengganggu dari dorongan untuk menentukan lebih ketat syarat dan ketentuan di mana organisasi nirlaba dapat berfungsi sebagai pemasok layanan adalah tekanan untuk mengubah sifat dan tujuan dari sektor sukarela. Pandangan ini menunjukkan bahwa jika organisasi nirlaba membiarkan visi mereka dipersempit menjadi 
hanya agen yang menyediakan layanan yang ditentukan oleh pemerintah dalam menanggapi kontrak tertentu, maka mereka akan menjadi tidak dapat dibedakan dari sub-kontraktor. Keuntungan komparatif dari organisasi semacam itu tidak hanya terletak pada kapasitas mereka untuk memobilisasi dukungan sukarela, tetapi juga dalam mengintegrasikan orang ke dalam komunitas melalui kegiatan pencegahan, pengembangan dan advokasi yang tidak mungkin menarik pendanaan karena mereka menghasilkan keluaran yang sulit diukur (Allison \& Kaye, 2005). Di tingkat informal, organisasi nirlaba yang menegaskan otonomi mereka dengan berusaha mempertahankan aktivitas khusus ini mungkin menemukan budaya mereka bentrok dengan budaya organisasi lokal manajerial hingga tingkat yang mengecualikan mereka dari peluang untuk terlibat. Namun, mereka mungkin dapat menjalin hubungan dengan anggota dewan dan pejabat yang mencari sumber dukungan eksternal untuk penolakan mereka terhadap manajerialisme (Allison \& Kaye, 2005).

Tampaknya ada sejumlah cara di mana pemerintah daerah dapat terlibat dengan organisasi nirlaba dengan cara yang mendorong pembentukan modal sosial. Misalnya, mereka dapat memberikan kesempatan kepada warga dan masyarakat untuk mempengaruhi hasil dari masalah dan keputusan lokal, fasilitas dan jenis infrastruktur yang memungkinkan asosiasi sukarela untuk berkembang dan berkembang, dan bantuan melalui hibah, nasihat dan pelatihan kepada orang-orang yang terlibat dalam mengembangkan layanan lokal. jaringan pengiriman. Mereka dapat melakukan pemantauan, penelitian dan pengumpulan data tentang kekuatan sektor sukarela lokal. Mereka juga dapat mengoordinasikan pemberian layanan dan pendanaan antar lembaga, asosiasi sukarela dan perusahaan untuk memastikan kebutuhan lokal terpenuhi, dan memberikan suara dan legitimasi kepada keprihatinan masyarakat tentang tingkat dan jangkauan layanan lokal, terutama jika layanan tersebut disediakan oleh instansi pemerintah pusat.

Dimensi kunci dari strategi ini adalah bahwa hubungan jaringan yang berusaha dibangun oleh pemerintah daerah dengan badan-badan lain, organisasi nirlaba dan kelompok masyarakat harus dalam bentuk kemitraan horizontal daripada hubungan prinsipal-agen atau patron-klien vertikal. Namun, jika kemitraan pemerintah daerah yang dibentuk dengan asosiasi sukarela bertujuan untuk melestarikan dan meningkatkan modal sosial, maka pemerintah daerah harus menghindari memperlakukan mereka seperti penyedia layanan lainnya dan mengakui perbedaan sifat sukarela atau keanggotaan dari organisasi-organisasi ini. Burstein (1998) berpendapat bahwa agar hal ini terjadi setidaknya ada dua faktor yang perlu dilindungi: kebebasan asosiasi ini untuk menentukan prioritas mereka sesuai dengan preferensi anggotanya; dan akuntabilitas utama yang mereka miliki kepada anggota mereka 
sendiri daripada kepada pendanaan eksternal atau badan sponsor. Oleh karena itu, pemerintah daerah harus melihat dirinya sebagai pendanaan inisiatif berbasis komunitas daripada membeli output yang ditentukan secara kontraktual dari organisasi nirlaba terkait.

Setelah pertimbangan diberikan pada peran yang dapat dimainkan oleh pemerintah daerah dalam pembentukan modal sosial, konsep yang sangat berbeda dari 'otoritas yang memungkinkan' muncul dari konsep yang hanya berupaya untuk memungkinkan pasar swasta untuk berpartisipasi lebih penuh dalam penyediaan layanan. Kami akan mempertimbangkan implikasi dari ini sebagai kesimpulan untuk makalah ini.

\section{KESIMPULAN}

Ledakan penelitian tentang modal sosial yang telah dilakukan oleh para ekonom, ilmuwan politik, dan sosiolog pada tahun 1990-an mungkin dengan demikian telah membantu pendukung otoritas yang memungkinkan dalam dua cara. Pertama, hal itu telah berkontribusi pada pemahaman yang lebih baik tentang hubungan empiris antara ukuran kuantitatif modal sosial dan indikator kinerja pemerintah daerah. Sejauh dapat diterima bahwa pergeseran ke otoritas yang memungkinkan merupakan langkah yang berpotensi meningkatkan modal sosial, maka literatur ini dapat dijadikan acuan dalam menilai manfaatnya. Kedua, literatur modal sosial juga menyediakan bahan studi kasus yang berkembang yang dapat digunakan untuk menjelaskan bagaimana pemerintah daerah dapat berfungsi sebagai organisasi yang menjembatani yang efektif.

\section{DAFTAR PUSTAKA}

Agung, Y. R., Fu'ady, M. A., \& Surur, M. (2018). Kohesi Sosial dalam Membentuk Harmoni Kehidupan Komunitas. Jurnal Psikologi Perseptual, 3(1), 37-43.

Allison, M., \& Kaye, J. (2005). Perencanaan Strategis Bagi Organisasi Nirlaba. Yayasan Pustaka Obor Indonesia.

Ancok, D. (2003). Modal Sosial dan Kualitas Masyarakat. Psikologika: Jurnal Pemikiran dan Penelitian Psikologi, 8(15), 4-14.

Annen, K. (2003). Social Capital, Inclusive Networks, and Economic Performance. Journal of Economic Behavior \& Organization, 50(4), 449-463.

Bel, G., Hebdon, R., \& Warner, M. (2007). Local Government Reform: Privatisation and Its Alternatives. Local government studies, 33(4), 507-515.

Bowles, S., \& Gintis, H. (2002). Social Capital and Community Governance. The economic journal, 112(483), F419-F436. 
Burstein, P. (1998). Bringing The Public Back In: Should Sociologists Consider The Impact of Public Opinion on Public Policy?. Social forces, 77(1), 27-62.

Castles, F. G. (2003). The World Turned Upside Down: Below Replacement Fertility, Changing Preferences and Family-Friendly Public Policy in 21 OECD countries. Journal of European social policy, 13(3), 209-227.

Coleman, J. S. (1988). Social Capital In The Creation Of Human Capital. American Journal of Sociology, 94, S95-S120.

Dasgupta, P. (2005). Economics of Social Capital. Economic Record, 81, S2-S21.

DeFilippis, J. (2001). The Myth of Social Capital in Community Development. Housing Policy Debate, 12(4), 781-806.

Dinda, S. (2008). Social Capital in The Creation of Human Capital and Economic Growth: A Productive Consumption Approach. The Journal of Socio-Economics, 37(5), 20202033.

Dollery, B., \& Robotti, L. (Eds.). (2008). The Theory and Practice of Local Government Reform. Edward Elgar Publishing.

Fafchamps, M. (2006). Development and Social Capital. The Journal of Development Studies, 42(7), 1180-1198.

Farazmand, A., \& Balilaj, A. (2015). Does Asia Have A Unique Theory of Public Administration for All Seasons? An Exploratory Essay. Asia Pacific Journal of Public Administration, 37(3), 143-160.

Hardin, R., Pateman, C., Weingast, B., \& Elkin, S. (2003). Deliberative Policy Analysis: Understanding Governance in The Network Society. Cambridge University Press.

Heckelman, J. C. (2007). Explaining the Rain:" The Rise and Decline of Nations" after 25 Years. Southern Economic Journal, 18-33.

Kriesi, H. (1996). The Organizational Structure of New Social Movements in a Political Context. Comparative perspectives on social movements, 152-184.

Meyer, D. S., \& Staggenborg, S. (1996). Movements, Countermovements, and the Structure of Political Opportunity. American journal of sociology, 101(6), 1628-1660.

Moloeng, L. J. (2007). Metodologi Penelitian Kualitatif. Bandung: Remaja Rosdakarya.

Putnam, R. D. (2000). Bowling Alone: America's Declining Social Capital. In Culture and Politics (pp. 223-234). New York: Palgrave Macmillan.

Putnam, R. D., \& Leonardi, R. (1993). Making Democracy Work: Civic Traditions in Modern Italy. Princeton University Press.

Siti Maryam, N. (2017). Mewujudkan Good Governance Melalui Pelayanan Publik. JIPSIJurnal Ilmu Politik dan Komunikasi UNIKOM, 6.

Soeprapto, R. (2003). Pengembangan Kapasitas Pemerintah Daerah Menuju Good Governance. Jurnal Ilmiah Administrasi Publik FIA Universitas Brawijaya, (4).

Suharto, E. (2000). Modal sosial dan kebijakan publik. Yogyakarta: FISIPOL Universitas Gadjah Mada

Syahra, R. (2003). Modal Sosial: Konsep dan Aplikasi. Jurnal Masyarakat dan Budaya, 5(1), $1-22$. 